\title{
Comparative Advantage of Tanzanian Coffee Sector under "Everything but Arms" Export Trading Regime
}

\author{
Abel Paul ${ }^{1 *}$ Charles Peter Mgeni ${ }^{1}$ Khamaldin Mutabazi $^{2}$ Reuben M.J. Kadigi ${ }^{2}$ \\ 1.Department of Agricultural Economics and Business Studies, Sokoine University of Agriculture, \\ P. O. Box 3007, Morogoro, Tanzania \\ 2.Department of Food and Resources Economics, Sokoine University of Agriculture, P. O. Box 3007, Morogoro, \\ Tanzania \\ *E-mail of the corresponding author: mahembeabel@gmail.com
}

\begin{abstract}
This paper assesses the comparative advantage of the Tanzanian coffee sector in the European Union (EU) before and during the Everything but Arms (EBA) trading regime. Coffee's comparative advantage at the EU level was compared to other commercial crops' comparative advantage namely; sisal, tobacco, cashew nuts, tea and cotton. To get a clear effect of the regime, Balassa Revealed Comparative Advantage (RCA) index has been employed to analyze exports values from 1995 to 2000 before EBA and from 2001 to 2019 during EBA as two separate periods. Findings from this study indicate that before EBA, coffee was a third product to be exported but during EBA it become a less specialized product. Therefore, EBA has promoted less the export of coffee to the EU market than expected that it will increase as the regime released transaction costs which were restricting the trade. To benefit from EBA preferential agreements, policymakers and sectorial stakeholders have to revisit EBA terms and conditions especially that of "Rule of Origin" which is reported as a major obstacle for most countries to utilize trade preferences agreements merely when they bump into low production within the country of origin.
\end{abstract}

Keywords: RCA, EAC, EBA, EU Market, Balassa Index

DOI: $10.7176 / \mathrm{JESD} / 13-4-02$

Publication date: February $28^{\text {th }} 2022$

\section{Introduction}

Coffee is one of the most produced, exported and widely consumed crops worldwide. International Coffee Organization (2015) reported that coffee is one of most commercial crops relevant for economic growth and poverty reduction. The largely produced and commercialized varieties of coffee worldwide are Arabica (Coffea Arabica) and Robusta (Coffea canephora). The leading coffee producers worldwide are Brazil, Vietnam, Colombia, Indonesia, Ethiopia, Honduras, India, Uganda and Mexico and Guatemala. According to Szenthe (2019), Tanzania ranked as the 18th country in coffee production. Most of the coffee produced from these countries is exported and a small portion is consumed domestically. The prime coffee importers are the European Union, Japan, Norway, the Russian Federation, Switzerland, Tunisia and the United States (International Coffee Organization, 2019).

Coffee production in Tanzania is aggravated by agro-ecological and climatic potentials such as abundant land with appropriate altitude, temperature, rainfall and soil suitable for high-quality Arabica and Robusta production (Mtaki, 2017). Arabica accounts for $70 \%$ of all coffee production in Tanzania while Robusta takes only $30 \%$ of the total country coffee production. Tanzanian Arabica coffee is grown on the slopes of Mount Kilimanjaro and Mount Meru in the Northern areas, under the shade of banana trees, also in the Southern Highlands of Songwe, Mbeya and Ruvuma regions where coffee is both intercropped with bananas and some areas are pure stand. Robusta coffee is grown in the western areas alongside Lake Victoria in the Kagera region (Tanzania Coffee Board, 2012). The marketing system of coffee in Tanzania has a unique form of conduct. According to the Tanzania Coffee Board (2019) and Mtaki (2017), coffee marketing in Tanzania has three systems; internal or farm gate market, coffee auction and direct export market. A large proportion of coffee produced in Tanzania is exported to the foreign market and less percentage is consumed domestically. According to Tanzania Coffee Board (2019), $93 \%$ of Tanzania coffee is exported, while only $7 \%$ is consumed locally.

Tanzania receives the great opportunity to trade goods and services with her trading partners located from different markets through various agreements in the world, including among others, Economic Partnership Agreements (EPA) - although signed but not yet ratified; African Growth and Opportunity Acts (AGOA); also, the Southern African Development Community (SADC); other markets are East African Community (EAC); Everything but Arms (EBA), a trading agreement between Least Developed Countries and the European Union and African Continental Free Trade Area (AfCFTA). These agreements aim to unlock trade barriers by promoting cross border investment, promoting the mobility of factors of production across borders and technological transfer. Thus, focusing on EBA this study aims to capture its activeness by analyzing the comparative advantage of the Tanzanian coffee sector in the EU market before and during the EBA trade regime.

Everything but Arms (EBA) is a scheme that grants the Least Developed Countries (LDCs) full duty-free and quota-free access to the EU single market for all products except arms and armaments that was enacted by United 
Nations (UN) in 2001 as a trade preference between EU and LDCs (European Commission, 2019). The regime aimed at increasing export earnings, promoting industrialization, and encouraging economic growth in the least developed countries. Currently, there are 48 beneficiaries under this arrangement and Tanzania is among beneficiaries of the EBA regime (European Commission, 2019). EBA as a special and different preference regime aim at promoting exports of Least Developing Countries with no impact of diving their home industries into a higher competition, hence termed as important catalysts for growth. A country shall be withdrawn from the list of EBA beneficiaries when a country is considered by the UN as a non-least developing country. The removal of a country from the arrangement and the establishment of a transitional period of at least three years shall be decided by the Commission, following the procedure referred to in the GSP Regulation (European Commission, 2019).

Unlike the Generalized Scheme of Preferences, entry into the EBA is involuntary and the EBA has no time limit regarding a particular country being considered "least developed country" by the United Nation. Before EBA, deployment of the preferences was at a minimal level, although about all products from Least Developed Countries were covered under those preferences schemes. This shows that EBA countries would use this preference to produce and trade more with EU countries. It is expected that in the removal of quota and duty to LDCs, these countries will gain more access to the EU market than were before. Despite laudable benefits from incentives provided by EBA, existing studies still debating its effects on the LDCs. It is argued that the initialization of EBA will have a restrictive outcome on export potential to the EU and welfare in LDCs. Therefore, this study seeks to assess the comparative advantage of the Tanzania coffee sector before and during the EBA regime. By assessing the comparative advantage of the Tanzania coffee sector relative to other commercial sectors exporting under EBA, the findings from this study will highlight how preferential agreements such as EBA promote exports from Least Developing Countries (LDCs). In addition, it will provide insight on appropriate strategies to be taken by coffee value chain actors, policymakers and sectoral stakeholders to benefit from the preferential agreements such as EBA.

\section{Literature review}

This section discuss on theoretical and conceptual framework and empirical review.

\subsection{Theoretical Framework}

Mwasha and Kweka (2014) stipulated that for any business to grow, theories are very necessary as they provide a road map and answers to significant questions such as why to trade, which category of goods and services to trade and how participants can benefit from trading. Holding other motives, the basic motivation of international trade is that of benefits to the trade participants (Dunn and Mutti, 2004; Salvatore, 2013). Researchers used the Heckscher-Ohlin (H-O) theory of international trade to govern this study. The theory comes into adoption as a critique of the previous theories of international trade.

Absolute advantage theory. The theory originated in 1776 by Adam Smith in his famous book "The Wealth of Nations". According to the theory, a country is said to have an absolute advantage if it can produce a particular product at a lower absolute cost than another country. Meant that, Smith assumed that each country could produce one or more commodities at a lower real cost than its trading partners (Dunn and Mutti, 2004). Adam Smith's theory enhanced that a country that trades across its borders can benefit from trade by specializing in producing and exporting products it can produce at lower absolute cost than other countries and importing products that it has an absolute disadvantage, hence increasing its welfare (Dunn and Mutti, 2004; Salvatore, 2013; Markusen et al., 1995; Krugman and Obstfeld, 2003; Smit, 2010). Based on the assumption of the theory that every country had an absolute advantage over another, the theory raises the following questions; What if a nation has an absolute advantage in producing everything, will the country continue to produce all the products for domestic consumption and exports? Will it be possible for both countries to trade and have mutual benefits when one country produces all the goods? A Comparative advantage theory has answered these questions.

Comparative advantage theory. In 1817, Ricardo presented the theory of comparative advantage in his publication of "Principles of Political Economy and Taxation". Ricardo argued that countries would still mutually benefit from trade, despite one country having an absolute disadvantage in the production of all commodities they trade relative to another country. One country has to specialize in the production and export of the product of its comparative advantage and import the product of its comparative disadvantage (Salvatore, 2013). Ricardo explained the theory of comparative advantage in terms of the labour theory of value although he did not believe in it. Ricardo used the labour theory of value only as a simple way to explain the theory of comparative advantage (Salvatore, 2013). Furthermore, labour is neither the only factor of production, it can be substituted with capital and other factors in the production of most commodities nor labour is homogeneous since it varies greatly in terms of training, production and wages.

Gottfried Haberler in 1936 rescued the theory of comparative advantage based on opportunity cost theory. According to the theory, a country would have a comparative advantage in the production of a commodity, if a particular commodity can be produced at a lower opportunity cost relative to the other country. The cost of a 
commodity is the amount of another commodity that must be foregone to proclaim just enough resources to produce one additional unit of the first commodity (Salvatore, 2013). The theory of comparative advantage, as discussed thus far, it does not explain the direction of the trade (Smit, 2010). This weakness conveys the need for an alternative model of comparative advantage to explain the direction of trade.

Heckscher-Ohlin (H-O) theory of international trade. The theory was developed by Swedish economists, Eli Heckscher and Bertil Ohlin in 1933. $\mathrm{H}$ - O theory examines differences in factor endowments as a source of international trade, which is a country that will have a comparative advantage in producing a product that is intensive in a relative factor that a country is abundant of. Heckscher - Ohlin theory is possible under underlying assumptions of constant returns to scale, two factors of production (labour and capital), equal technology in production, perfect competition in commodities and factor markets between countries, no market distortions and perfect factor mobility within each nation but factor immobile across countries (Markusen et al., 1995; Krugman and Obstfeld, 2003; Salvatore, 2013).

Most of the modern international trade theories such as intra-trade theory, international product life cycle trade theory and theory of Porter's national competitive trade theory were modifications and extensions of $\mathrm{H}-\mathrm{O}$ theory and their modifications did not reduce the rationality of the theory in enlightening the direction of trade between trading partners. However, all classical, neo-classical and new trade theories approved that nations engage in international trade because of the benefits received from trading.

\subsection{Conceptual Framework}

The framework briefly illustrates the comparative advantage of the Tanzanian coffee sector. The framework for this study is delineated in Figure 1. The figure illustrates that Tanzania trades to the EU market under the EBA preferential trading regime. As can be observed in Figure 1, under EBA, Tanzania exports its agricultural products including coffee to the EU market under duty and quota-free arrangements. Tanzania's comparative advantage or disadvantage in exporting a particular product is determined by the revealed comparative advantage which illustrates how a country's coffee export dominate the market in contrast to other commercial sectors. Revealed comparative advantage is regarded as the ratio of the share of a country's export in coffee in its total exports to the share of the world export of coffee in total world exports in the EU.

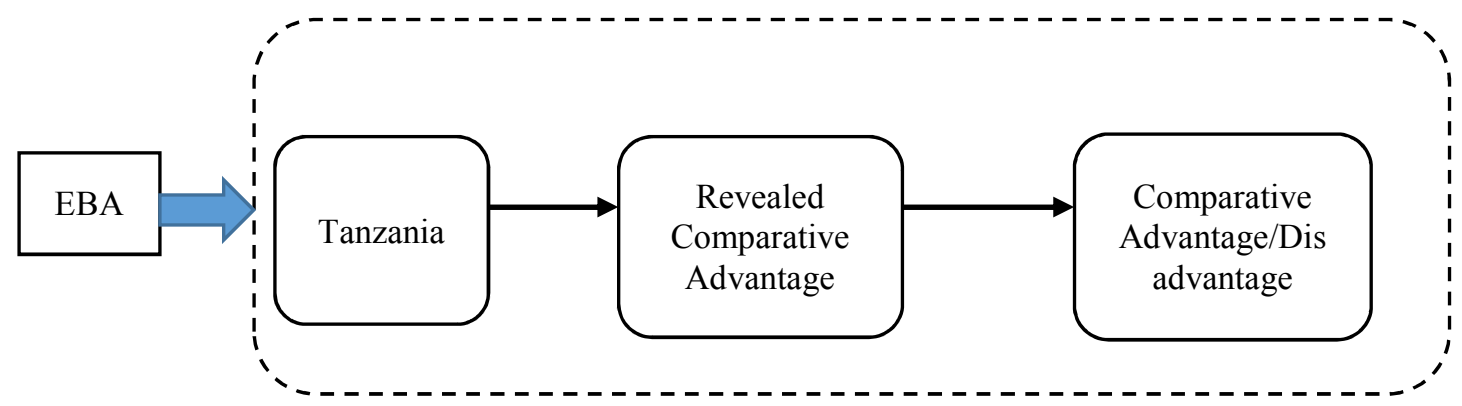

Figure 1: Conceptual framework

RCA index, the determinant of a country's comparative advantage or disadvantage is constituted by variables including the value of Tanzanian coffee exports, the value of coffee exported by the world in the EU market and lastly with the total export value of the world in the market. The country has an RCA index equal to or greater than one reveals that the country has a comparative advantage in coffee specialization and exportation, while a comparative disadvantage is evidenced by an RCA index of less than one. Therefore, with the baseline of H-O theory and variables relationship illustrated in the framework. The study computed the ratio of the share of a particular commercial product to Tanzania's total export to the share of that product to the world's total export in the market to manage the determination of the comparative advantage or disadvantage before and during the EBA preferential trade agreement.

\subsection{Empirical Review}

Revealed Comparative Advantage (RCA) possesses different characteristics for judging the comparative advantage of the country. RCA determine how a country is specialized in the production and trade of a certain product. RCA hypothesizes that a country is said to have revealed comparative advantage if the RCA index is greater or equal to one, otherwise a country has a comparative disadvantage. Several studies exist on the revealed comparative advantage showing it as the best tool used in the dynamic competitive market economy.

Geda and Yimer (2019) examined the effects of the African Continental Free Trade Area (AfCFTA) agreement tariff reduction protocol on intra-Africa's merchandise trade to identify its effects on trade creation and diversion. The trade indices including RCA show the restrictive effects of the AfCFTA in influencing trade 
creation but strong possibility in affecting trade diversion.

According to Chingarande et al., (2013) who investigated the comparative advantage of the EAC member states found that Kenya has a comparative advantage in 778 product lines, followed by Tanzania with 471 product lines, the third member stare is Uganda with 437 product lines, then Rwanda with 275 product lines and the last is Burundi with 152 product lines. The data used to compute the RCA of the EAC member states was obtained from the International Trade Centre (ITC) at Harmonized System 6-digit level.

Mwasha and Kweka (2014) also utilized RCA to analyse the revealed comparative advantage for the topmost export sectors and commodities in Tanzania from 2009 to 2012. In analysing the revealed comparative advantage of Tanzania in the face of international trade, Balassa's (1965) index was computed for various sectors at the Harmonized System 4-digit disaggregated level of commodity classification from UN COMTRADE statistics database and International Trade Centre (ITC). The results demonstrate that traditional cash crops sectors such as coffee, tea and spices and commodities found mineral resources experience RCA greater than one, hence becoming the leading export sector and commodities under the study period.

Abtew (2015) used RCA to empirically analyse the revealed comparative advantage of Ethiopian leather industry products relative to Kenya, Egypt and Tunisia. Balassa index was calculated using leather industry data from 2004 to 2013 which classified at the HS code 41 for raw hides and skins and HS code 42 for leather and leather products. The data was classified at a 2-digit level. The study findings revealed that Ethiopia has a high RCA in rawhide and skins exports over the selected African countries. This postulates that Ethiopia has significant potential growth for specification in both raw hides and skins and leather product export.

Abtew (2017) examined the RCA of the footwear sector in Ethiopia, Egypt, Kenya, Nigeria, Tanzania and Uganda using Balassa (1965) RCA and 2003-2014 export data at the 2-digit level with HS code 64 to investigate the RCA exhibition among selected African countries. The findings suggested that only Kenya has the mean RCA of greater than one, with the remaining countries RCAs below one which implies a comparative disadvantage.

Gupta and Kumar (2017) used Balassa Revealed Comparative Advantage (RCA) index to analyse the revealed comparative advantage of the exports of Rwanda based on 2001-2015 export data disaggregated at 4digit and 6-digit level HS-1996 classification. They found that coffee, tea, mate and spices experienced an RCA index of 81.46 in 2015, which occupied a top ten products position with the highest RCA for Rwanda.

In a recent study, Dyegula and Lwesya (2018) examined the extent of trade liberalization in the Southern African Development Community (SADC) regional trade area, and the economic benefits derived from Tanzania's membership between 2000 and 2009. Their study used RCA to investigate the products with which the region had a comparative advantage. The results revealed that coffee was not among the top ten products in which the SADC region has a revealed comparative advantage. Instead, the results suggested that SADC had an RCA on products like live trees, other plants, edible fruit and nuts, tobacco, ores, slag and ash, precious metals and base metals. These were agricultural, intermediate goods and ores and minerals products.

In another study, Muchanyuri and Mzumara (2013) analysed the inter-sectorial comparative advantage of Tanzania and its impact on international purchasing. The study adopted the Balassa RCA index to analyse export data for 2008, 2009 and 2010 disaggregated at a 6-digit level. In inter-sectorial comparative advantage analysis in Tanzania, the vegetable products sector ranks number one with 90 products with RCA greater or equal to one. The followed by the textiles sector as the second sector with 75 products with RCA equal or greater than one. The third position is held by the machinery/ electronic sector with 52 products with RCA equal or greater than one. The results show cashew nuts, cloves and coffee are the top three products in the vegetable sector in which Tanzania has a comparative advantage with an average RCA of 587.80, 322.75 and 302.92 respectively. The results endorse that the vegetable products sector is the most competitive in the country. Therefore, in terms of international purchasing, other SADC countries would benefit if they import products from Tanzania's vegetable products sector.

Ndayitwayeko et al., (2014) used an improved Normalized Revealed Comparative Advantage (NRCA) to investigate the comparative advantage of Burundi's coffee that accounts for about $75 \%$ of the county's total exports in the international market. The analysis was done based on coffee exports data of Standard International Trade Classification (SITC) 3; 4-digit level for the period 2000 to 2012. The empirical findings from NRCA suggest that EAC countries had a comparative advantage in specialization in coffee export. Burundi exhibits the least comparative advantage for coffee among all EAC coffee-growing member states. The first position was held by Uganda, then Kenya and followed by Tanzania and Rwanda.

Another study that attempts to employ the RCA is the study of Katunze and Kuteesa (2016) the study examined RCA by using Symmetric Index (SI) which was first engineered by Laursen (1998) to account for the asymmetry problem. The study evaluated the stability of Uganda's revealed comparative advantage in Common Market for Eastern and Southern Africa (COMESA). The evaluation was done using data from 1997 to 2014 at a 6-digit level HS export and re-exports data extracted from the World Integrated Trade Solution (WITS). Findings revealed that Uganda has RCA in all 16 industries evaluated at the product chapter level which meant that Uganda is stable in exporting animals, vegetables, food production, wood, textiles and cloth, stone and grass and metals to 
the COMESA regional trade area.

In a different study, Mkenda (2014) examined Tanzania's structural transformation using RCA based on global and country export data of 2001, 2002 and 2011 that classified at the 2-digit level of the HS. The study compared the comparative advantage of agricultural products, fish and minerals against other product groups. The study's RCA values showed that for 2001 and 2011 Tanzania's comparative advantage was strongly dominated by the agricultural products $-70 \%$ of the product groups were agricultural - with the remaining products being mineral-based. Coffee, tea, mate and spices with HS-code 09 was the topmost product group in 2001, and in 2011 the product group was in the top three among the top ten product groups with the highest RCA indices.

However, none of these studies has focused on measuring the effects of special trade agreements to the benefiting member states especially those which offer duty-free and quota-free like EBA. As a labour-intensive sector, the coffee sector of Tanzania has a high potential to attract resources for specialization and export performance. When least developed countries are granted duty-free and quota-free in a particular sector, resources will move towards that sector. Therefore, this study estimated the revealed comparative advantage to provide insight on how the Tanzanian coffee sector comparative advantage was before EBA and during EBA as a special and unique preference of exporting its products to the EU market.

\section{Methodology}

This section presents the methodology used in this study. This section dwells on the type and sources of data collected, the study countries, data processing and analysis and model specification.

\subsection{Study Area}

The study covered six commercial sectors in Tanzania; Coffee, Sisal, Tobacco, Cashew nut, Tea and Cotton to provide insight on Tanzania coffee sector comparative advantage relative to other commercial sectors. According to BOT (2020), these crops are known as traditional cash crops and their exports are called traditional goods exports. Focusing on the coffee export sector the study reveals how Tanzania has a comparative advantage in exporting coffee to the EU 28 countries. Coffee's comparative advantage at the EU level was compared to other commercial crops comparative advantage at the EU level, namely: Sisal, Tobacco, Cashew nut, Tea and Cotton.

\subsection{Data Used}

This paper retrieved the export data from World Integrated Trade Solution (WITS) and International Trade Centre (ITC). Data used to describe the export performance of Tanzanian coffee from 1995 to 2000 was obtained from WITS and that from 2001 to 2019 was from ITC. Due to the unavailability of enough export data before EBA, only export data for six years were compiled to estimate the RCA indices before EBA. Data used to assess Tanzania's comparative advantage in exporting agricultural products to the EU before and during EBA was extracted from WITS. The export values are recorded in US Dollars thousand at Standard International Trade Classification (SITC) Revision 3.

\subsection{Model Specification}

Revealed comparative advantage (RCA) methodology was employed to estimate a country's comparative advantage or comparative disadvantage in coffee export to the EU market before and during the establishment of the EBA initiative in 2001. Revealed comparative advantage (RCA) is the ratio of the share of a country's export in a particular good in its total exports to the share of world exports of that product in total world exports. RCA indices use trade pattern to analyze regional, sectorial or commodity comparative advantage or disadvantage by contrasting the country of interest trade profile with the rest world's average. Therefore, the study adopted the Balassa index of 1965 to analyse Tanzania's comparative advantage before EBA (1995-2000) and during EBA (2001-2019) using international trade data.

$$
\operatorname{RCA}_{\mathrm{ij}}=\left(\mathrm{X}_{\mathrm{ij}} / \mathrm{X}_{\mathrm{it}}\right) /\left(\mathrm{X}_{\mathrm{wj}} / \mathrm{X}_{\mathrm{wt}}\right)
$$

Where;

RCAij - represent the Revealed Comparative Advantage of Tanzania for product $\mathrm{j}$

Xij - export of good j by Tanzania

Xwj - world's export of product $\mathrm{j}$

Xit - Tanzania's total exports

Xwt - total world exports.

RCA takes values between zero and positive infinite. A country is said to have a revealed comparative advantage in a particular product or service if RCA Index equals or exceed one. However, less than one RCA value reveals that the country is disadvantageous and has not specialized in the specified product or service line.

The use of the revealed comparative advantage index has it is advantageous and disadvantageous. The 
advantage of using the RCA index to reveal a country's comparative advantage is that the methodology is bided with the changes in an economy's relative factor endowment and factor intensity. However, its disadvantages are that it might be affected by any intervention that distorts the trade pattern and cannot detect the source of comparative advantage or disadvantage. The RCA become popular after the application of the neoclassical $\mathrm{H}-\mathrm{O}$ theory when one wants to measure the comparative advantage of a nation due to the unobservable relative price and production costs (Ndayitwayeko and Ndimanya, 2015).

\section{Results and Discussion}

This section developed to present the export performance of Tanzanian coffee and the RCA results estimated before and during the EBA. The aim of providing this coffee trade information is to extend the coffee trade performance history of the country, whereby RCA estimation intends to measure the contribution of EBA initiatives in exporting coffee to the EU market.

\subsection{Tanzania coffee export values and share (1995-2000)}

Tanzania is among the certified coffee exporting countries with a country code of 033 and Tanzania Coffee Board (TCB) as certified agent exporting coffee using Dar es Salaam and Tanga as registered ports (ICO, 2011). Coffee is one of the most commercial crops exported by Tanzania worldwide (BOT, 2020). From 1995 to 2000, Tanzania exported coffee to the EU valued at an average of US\$ 60323.45033 Thousand with minimum export value in 1998 and maximum export value in 1997. In 1997, Tanzania exported coffee valued at US\$ 73087.696 Thousand, resulting in $31.86 \%$ share of the country's total export in the entire EU market, while in 1998, the exported value was US\$ 43147.695 Thousand and its contribution to the country's total export in the EU was $22.73 \%$ (Figure 2).

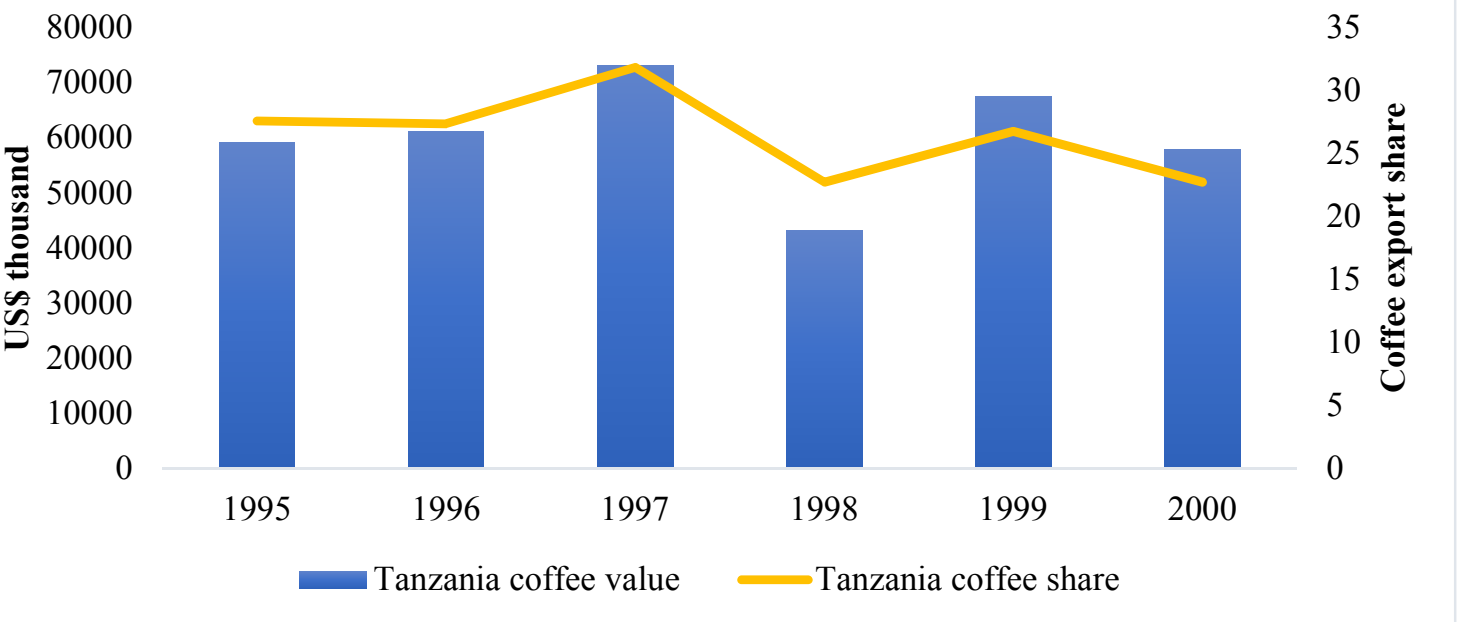

Figure 2: Tanzania coffee export values and share

Source: ITC Database, 2020

\subsection{Destination markets for coffee exported by United Republic of Tanzania (2001-2019)}

Figure 3, Figure 4 and Figure 5 show the destination markets for coffee exported by Tanzania from 2001 to 2019. Figure 3 represents total export quantities and values of coffee imported by the top $10 \mathrm{EU}$ countries. As is shown in Figure 3 that Tanzania coffee export in the EU relies almost entirely upon Germany, Italy and Belgium. The other major EU importing countries are Finland, the Netherlands, the United Kingdom and Spain. The list also includes Sweden, France and Denmark. For the period 2001 to 2019 the quantity of coffee imported by Germany was 166286 Tons valued at US\$ 358759 Thousand, while that of France was 6879 Tons with a value of US\$13645 Thousand. 


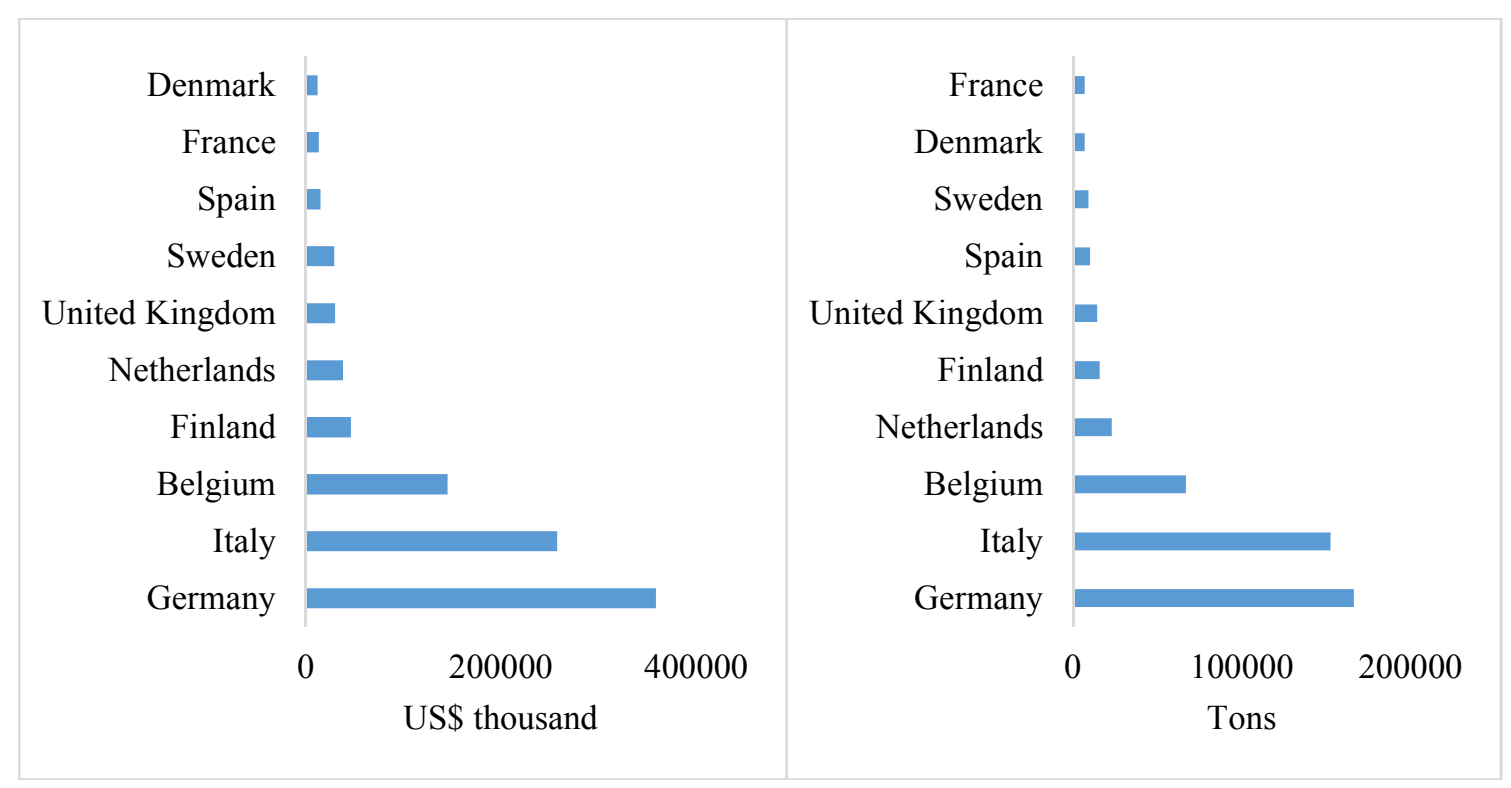

\section{Figure 3: Top 10 EU importers of coffee from Tanzania}

Source: ITC Database, 2020

The structure of Tanzania coffee export to countries other than EU countries is shown in Figure 4. The main imports of coffee from Tanzania dominated by Japan which imports 168078 Tons of coffee valued at US\$ 516054 Thousand, followed by the United States of America and Switzerland that import 66479 Tons and 15070 Tons valued at US\$ 222133 Thousand and US\$ 24830 Thousand, respectively. As reported in Figure 5, Israel, the Russian Federation, the Republic of Korea and Singapore, together with Canada, Australia and India were among the top 10 non-EU importers of coffee from Tanzania under the reported period of 2001 to 2019.

$$
\begin{array}{r}
\text { India } \\
\text { Singapore } \\
\text { Australia } \\
\text { Canada }
\end{array}
$$

Korea, Republic of

Switzerland

Russian Federation

Israel

USA

Japan

$0 \quad 200000400000600000$

US\$ thousand

\section{India \\ Australia \\ Canada \\ Singapore}

Korea, Republic of

Russian Federation

Israel

Switzerland

USA

Japan

$0 \quad 100000 \quad 200000$

Tons

Figure 4: Top 10 non-EU importers of coffee from Tanzania

Source: ITC Database, 2020

In the period of 2001-2019, in the African market, Tanzania exported more coffee to Uganda, Morocco, South Africa and Algeria. Other top 10 African countries coffee importers from Tanzania are Eswatini, Tunisia, Kenya, Eritrea, Egypt and Rwanda. Uganda imported more coffee, it imported 13430 Tons, followed by morocco with 12516 Tons and South Africa imports 7874 Tons as a third large coffee importer from Tanzania (Figure 5). Regardless of Uganda having a large quantity of coffee imported from Tanzania, its coffee is valued only at US\$912 Thousand, very far from South Africa and Morocco whose coffee was valued at US\$29375 Thousand and US\$ 21395 Thousand, respectively. This might be impacted by the currency value of importing countries. 


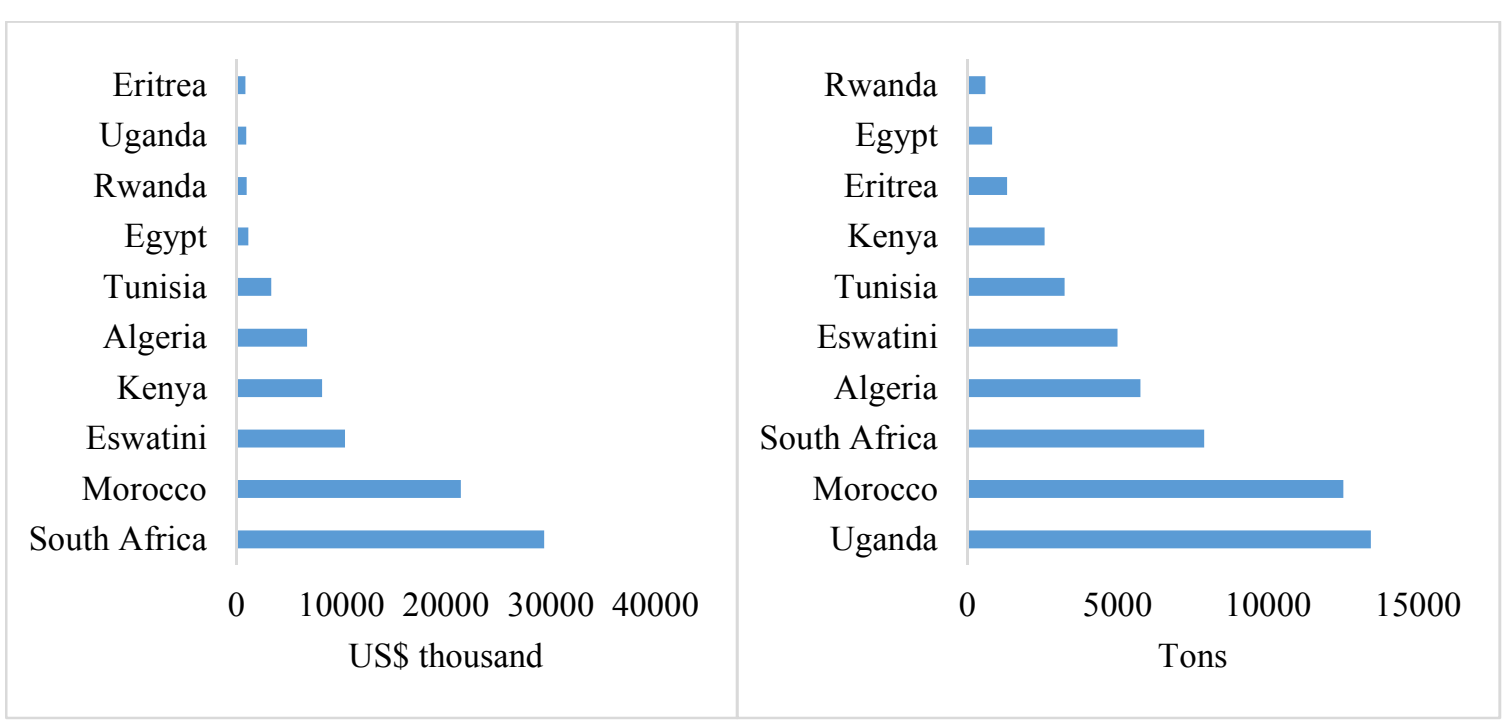

Figure 5: Top 10 Africa importers of coffee from Tanzania

Source: ITC Database, 2020

It is in Figure 6 where it's shown that $57 \%$ of Tanzanian coffee is exported to the EU market, this is higher than other markets, $37 \%$ of coffee is exported outside the EU and only $6 \%$ of the coffee is exported to African counties. The quantity of coffee exported to the EU market is $20 \%$ and $51 \%$ more of that exported to outside EU and Africa markets, respectively. Coffee that is exported to the EU market contributes $49 \%$ of Tanzanian coffee export value, only $2 \%$ more than that contributed by markets outside the EU. Coffee export outside the EU dominates $47 \%$ of all Tanzanian coffee export value, while that exported in Africa brings only $4 \%$ of the total export value of the country's coffee.

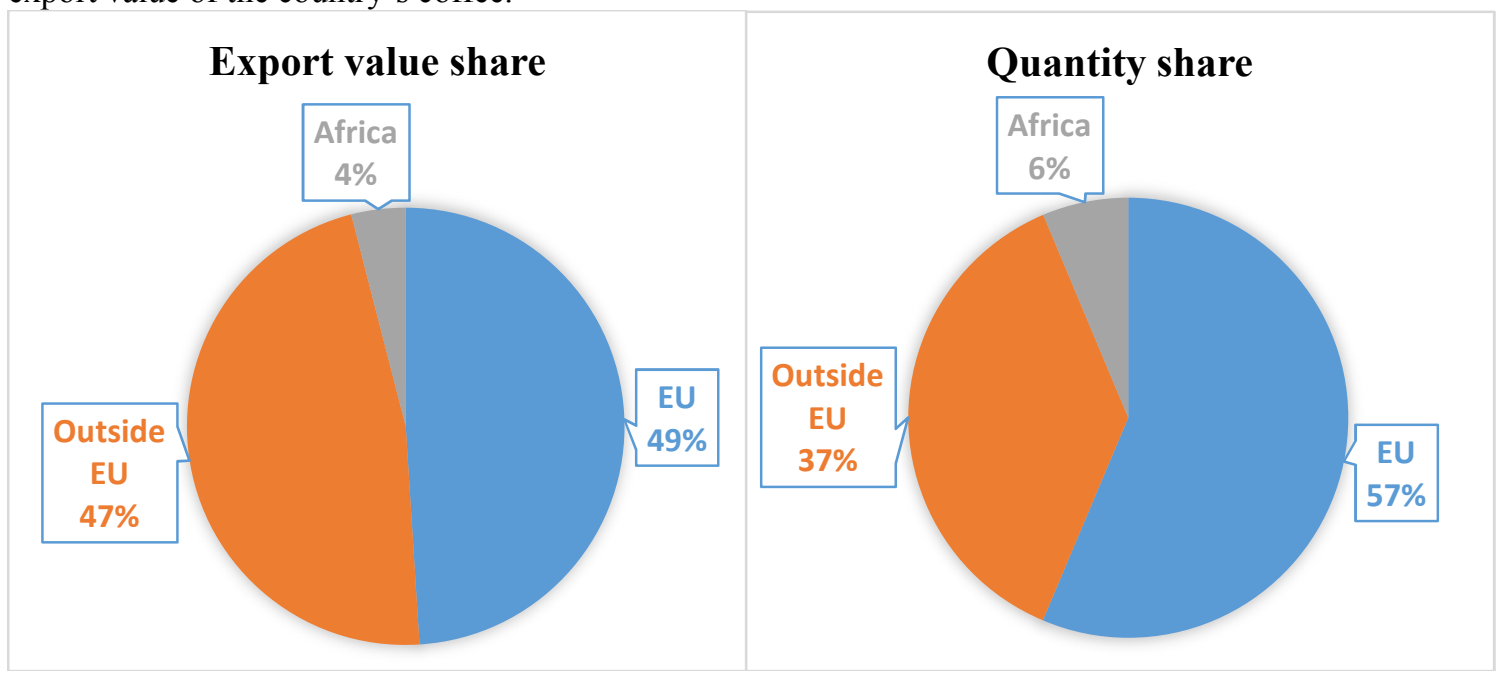

Figure 1: Coffee export and values share distribution

Source: ITC Database, 2020

\subsection{Revealed Comparative Advantage (RCA)}

The RCA results were estimated before and during the EBA. The aim of running this prior and during EBA estimation was to provide insights on how the Tanzanian coffee sector comparative advantage was before and during the establishment of EBA in 2001. The prior analysis intends to know the RCA of a country before receiving a special and unilateral preference of exporting its products to the EU market under the elimination of quota and duties.

Before EBA, Tanzania has revealed comparative advantage (RCA) greater or equal to one in all six products. This signifies that Tanzania is highly specialized in producing and exporting such primary products to the EU market (Table 1). Tanzania has a very high RCA of 1859.4 in the production and export of sisal and agave fibres, raw (26541 HS). The second position is dominated by tea $(0741 \mathrm{HS})$ with an RCA of 110.6 . It is followed by coffee (071 HS) which has an RCA of 48.7. Cotton (263 HS) occupies the fourth position, having an RCA of 41.4. The least two specialized products were tobacco/ manufactures (12 HS) and cashew nuts, fresh/ dried (05773 HS) 
with RCA 23.2 and 19.4, respectively. However, coffee featured among the top three products which Tanzania specialized in exporting to the EU before EBA. This implies that coffee was among agricultural products that widen the scope of international trade flow.

Table 1: RCA of Tanzanian commercial crops to the EU before EBA

\begin{tabular}{|l|l|l|l|l|l|l|l|l|}
\hline $\begin{array}{l}\text { HS } \\
\text { Code }\end{array}$ & $\begin{array}{l}\text { Commodity } \\
\text { description }\end{array}$ & $\mathbf{1 9 9 5}$ & $\mathbf{1 9 9 6}$ & $\mathbf{1 9 9 7}$ & $\mathbf{1 9 9 8}$ & $\mathbf{1 9 9 9}$ & $\mathbf{2 0 0 0}$ & $\begin{array}{l}\text { Average } \\
\text { RCA }\end{array}$ \\
\hline 05773 & $\begin{array}{l}\text { Cashew nuts, fresh/ } \\
\text { dried }\end{array}$ & 18.2 & 13.6 & 1.8 & 32.4 & 10.4 & 40.3 & 19.4 \\
\hline 071 & Coffee & 43.5 & 51.8 & 47.1 & 38.4 & 56.1 & 55.2 & 48.7 \\
\hline 0741 & Tea & 125.4 & 128.3 & 112.6 & 104.9 & 103.6 & 88.5 & 110.6 \\
\hline 12 & Tobacco/ manufactures & 25.4 & 23.1 & 31.2 & 22.3 & 21.0 & 16.2 & 23.2 \\
\hline 263 & Cotton & 40.5 & 42.2 & 67.8 & 20.1 & 56.9 & 21.1 & 41.4 \\
\hline 26541 & Sisal/ agave fibres, raw & 2334.7 & 2214.9 & 1320.5 & 2515.0 & 1462.4 & 1308.9 & 1859.4 \\
\hline
\end{tabular}

Source: Computed using the data from WITS, 2020

Results in Table 2 present the RCA indices of Tanzania respective to the EU in six agricultural products during the EBA export regime. The highest level of RCA Tanzania has in sisal and agave fibres, raw (26541 HS) with an average RCA of 595.8, followed by tea (0741 HS) having RCA of 76.6, cashew nuts, fresh/ dried (05773 HS) with an RCA of 59.4 and tobacco/ manufactures (12 HS) which has RCA of 46.0. Cotton (263 HS) is the least specialized in Tanzania during EBA. It has an RCA of 32.3. It is followed by coffee (071 HS) in being less specialized. Coffee has an RCA of 29.8. Generally, all these products are exported as primary products, which means that the value is added elsewhere instead of being done in Tanzania.

Table 2: RCA of Tanzanian commercial crops to the EU during EBA

\begin{tabular}{|l|l|l|l|l|l|l|}
\hline HS Code & 05773 & 071 & 0741 & 12 & 263 & 26541 \\
\hline $\begin{array}{l}\text { Commodity } \\
\text { description }\end{array}$ & $\begin{array}{l}\text { Cashew nuts, } \\
\text { fresh/ dried }\end{array}$ & Coffee & Tea & $\begin{array}{l}\text { Tobacco/ } \\
\text { manufactures }\end{array}$ & Cotton & $\begin{array}{l}\text { Sisal/ } \\
\text { fibres, raw }\end{array}$ \\
\hline $\mathbf{2 0 0 1}$ & 25.6 & 49.9 & 61.5 & 18.4 & 30.7 & 1651.2 \\
\hline $\mathbf{2 0 0 2}$ & 31.4 & 28.3 & 86.3 & 22.4 & 27.7 & 1976.1 \\
\hline $\mathbf{2 0 0 3}$ & 41.9 & 41.8 & 78.9 & 23.8 & 31.7 & 1691.3 \\
\hline $\mathbf{2 0 0 4}$ & 82.6 & 37.3 & 87.4 & 35.3 & 35.4 & 1853.8 \\
\hline $\mathbf{2 0 0 5}$ & 33.5 & 39.0 & 82.0 & 61.7 & 91.0 & 1618.1 \\
\hline $\mathbf{2 0 0 6}$ & 95.9 & 37.3 & 86.5 & 44.3 & 53.6 & 1198.2 \\
\hline $\mathbf{2 0 0 7}$ & 119.7 & 61.6 & 84.3 & 39.3 & 49.4 & 1332.2 \\
\hline $\mathbf{2 0 0 8}$ & 139.8 & 33.4 & 85.6 & 61.3 & 70.9 & 0.0 \\
\hline $\mathbf{2 0 0 9}$ & 141.2 & 35.5 & 127.5 & 36.4 & 63.2 & 0.0 \\
\hline $\mathbf{2 0 1 0}$ & 122.8 & 27.3 & 105.9 & 45.1 & 28.1 & 0.0 \\
\hline $\mathbf{2 0 1 1}$ & 84.3 & 19.8 & 69.7 & 29.0 & 19.6 & 0.0 \\
\hline $\mathbf{2 0 1 2}$ & 75.7 & 22.9 & 90.9 & 46.6 & 4.7 & 0.0 \\
\hline $\mathbf{2 0 1 3}$ & 89.4 & 35.0 & 104.9 & 34.4 & 27.5 & 0.0 \\
\hline $\mathbf{2 0 1 4}$ & 30.9 & 17.5 & 54.8 & 64.6 & 10.7 & 0.0 \\
\hline $\mathbf{2 0 1 5}$ & 1.7 & 18.8 & 46.9 & 81.0 & 13.0 & 0.0 \\
\hline $\mathbf{2 0 1 6}$ & 2.4 & 19.5 & 52.9 & 95.0 & 14.1 & 0.0 \\
\hline $\mathbf{2 0 1 7}$ & 6.7 & 20.8 & 61.7 & 63.9 & 24.7 & 0.0 \\
\hline $\mathbf{2 0 1 8}$ & 0.0 & 1.4 & 28.4 & 2.0 & 0.5 & 0.0 \\
\hline $\mathbf{2 0 1 9}$ & 3.7 & 19.0 & 59.2 & 69.1 & 18.1 & 0.0 \\
\hline Average RCA & 59.4 & 29.8 & 76.6 & 46.0 & 32.3 & 595.8 \\
\hline
\end{tabular}

Source: Computed using the data from WITS, 2020

\section{Conclusion}

Tanzania has a revealed comparative advantage for its traditional cash crops before and during EBA. Comparatively, the RCA indices during EBA were less than those before EBA. From the results, it has been observed that sisal and agave fibres, raw and tea have high levels of RCA compared to other products before and during EBA. Sisal and agave fibres, raw in both separate periods of the time featured as a significant potentiality of being exported to the EU market although since 2008 it has never been exported. However, before EBA, coffee was a third product to be exported but during EBA it become a less specialized product. On the contrary, the fourth position was occupied by cotton before EBA and was the fifth during EBA. Tobacco/ manufactures and cashew nuts, fresh/ dried hold fifth and sixth place before EBA but during EBA cashew nuts, fresh/ dried was the third product to be exported, while tobacco/ manufactures holds the fourth place. The study has revealed that during EBA coffee occupies a small proportion of the country's total exports to the EU market. Therefore, EBA has less 
promoted the export of coffee to the EU market than expected that it will increase as the regime released transaction costs which were restricting the trade flows, as its RCA index decreased compared to that before the regime. The study suggests that for Tanzania to benefit from EBA preferential agreement, coffee value chain actors, policymakers and sectorial stakeholders have to revisit EBA terms and conditions especially that of "Rule of Origin" which is reported as a major obstacle for most countries to utilize trade preference agreements merely when they bump into low production within the country of origin.

\section{Acknowledgements}

Authors owe their deeply thankful to the African Economic Research Consortium (AERC) and TRADE-Hub Project for their financial and materials support that made this research work soundly accomplished.

\section{References}

Abtew, M. A. (2015). Revealed Comparative Advantage of Ethiopian Leather Industry with Selected African Economies. International Journal of Business and Economics Research 4(5): 229-237. doi: https://doi.org/10.11648/j.ijber.20150405.11.

Abtew, M. A. (2017). Revealed Comparative Advantage of Footwear Industry: An Empirical Analysis for Selected African Countries. International Research Journal of Business and Management-IRJBM X(13): 57-73.

Balassa, B. (1965). Trade Liberalisation and "Revealed" Comparative Advantage. The Manchester School.

Chingarande, A., Mzumara, M., and Karambakuwa, R. (2013). Comparative Advantage and Economic Performance of East African Community (EAC) Member States. J Economics 4(1): 39-46.

Dunn, R. M. and Mutti, J. H. (2004). International Economics (Sixth Edition). Routledge, London and New York. 544pp.

Dyegula, N., and Lwesya, F. (2018). Trade Liberalisation in SADC and the Economic Benefits of Belonging to an RTA : The Case of Tanzania. Studies and Scientific Researches. Economics Edition, (27): 56-74.

East African Cummunity (2016). East African Community Vision 2050: Regional Vision for Social-Economic Transformation and Development. EAC Secretariat, Arusha, Tanzania. 112pp.

European Commission. (2019). List of Generalized System of Preferences (GSP) beneficiary countries. [https://ec.europa.eu/trade/policy/countries-and-regions/development/generalised-scheme-of-preferences/] site visited on $22 / 8 / 2020$.

Geda, A. and Yimer, A. (2019). The Trade Effects of the African Continental Free Trade Area (AfCFTA): An Empirical Analysis. Research Gate: 1 - 47.

Gupta, M. and Kumar, H. (2017). Revealed Comparative Advantage : An Analysis of Exports of Rwanda. IOSR Journal of Economics and Finance (IOSR-JEF) 8(3): 69-76. doi:https://doi.org/10.9790/5933-0803036976.

International Coffee Organization (2011). List of Exporting Countries and their Country Codes, ICO Certifying Agents and Registered Ports of Exports. International Coffee Council, London, United Kingdom. 12pp.

International Coffee Organization. (2015). Sustainability of the coffee sector in Africa, International Coffee Council Report. 2 - 6 March, 2015, London, United Kingdom. 29pp.

International Coffee Organization. (2019). World Coffee Market Report. [http://www.ico.org] site visited on $12 / 4 / 2020$.

International Trade Centre (2020). List of importing markets for a product exported by Tanzania, United Republic of Product: 0901 Coffee, whether or not roasted or decaffeinated; coffee husks and skins; coffee substitutes containing coffee in any proportion. [https://www.trademap.org/Country_SelProductCountry_TS.aspx?nvpm=1\%7c834\%7c\%7c\%7c\%7c0901\% $7 \mathrm{c} \% 7 \mathrm{c} \% 7 \mathrm{c} 4 \% 7 \mathrm{c} 1 \% 7 \mathrm{c} 1 \% 7 \mathrm{c} 2 \% 7 \mathrm{c} 2 \% 7 \mathrm{c} 1 \% 7 \mathrm{c} 2 \% 7 \mathrm{c} 1 \% 7 \mathrm{c} 1 \% 7 \mathrm{c} 1]$ site visited on 16/12/2020.

Katunze, M. and Kuteesa, A. (2016). Uganda's Revealed Comparative Advantage in COMESA. Journal of Sustainable Development 9(3): 192-207. doi:https://doi.org/10.5539/jsd.v9n3p192.

Krugman, P. R. and Obstfeld, M. (2003). International Economics: Theory and Policy. In D. Clinton, J. Tufts, J. Rigney, and A. Basso (Eds.), Pearson Education, Inc. (Sixth Edit). Elm street publishing services. 737pp.

Laursen, K. (1998). Revealed Comparative Advantage and the Alternatives as Measures of International Specialization, [DRUID Working Paper, 98-30]. Retrieved from http://www3.druid.dk/wp/19980030.pdf.

Markusen, J. R., Melvin, J. R., Maskus, K. E. and Kaempfer, W. (1995). International Trade: Theory and Evidence. In S. D. Stratford and L. H. Sutton (Eds.), McGraw-Hill, Inc., New York. 248pp.

Mtaki, B. (2017). Tanzania Coffee Annual Report. FAS, Dar es Salaam, Tanzania. 4pp.

Mkenda, B. K. (2014). Tanzania's Revealed Comparative Advantage and Structural Transformation. Botswana Journal of Economics 12(1): 59-81.

Muchanyuri, B. and Mzumara, M. (2013). Inter-Sectoral Comparative Advantage of Tanzania and Impact on International Purchasing. Greener Journal of Business and Management Studies 3(8): 361-368. doi: https://doi.org/10.15580/gjbms.2013.8.102913937.

Mwasha, N. A., and Kweka, Z. (2014). Tanzania in the Face of International Trade: The Analysis of Revealed 
Comparative Advantage from 2009 to 2012. International Journal of Business and Economics Research 3(1): 15-28. doi:https://doi.org/10.11648/j.ijber.20140301.13.

Ndayitwayeko, W. and Ndimanya, P. (2015). Dynamics of Tea Trade Competitiveness in EAC : Evidence from Tea Exports of Burundi. Journal of Economics and Sustainable Development 6(12): 154-161. www.iiste.org

Ndayitwayeko, W. M., Odhiambo, M. O., Korir, M., and Nyangweso, P. M. (2014). Comparative Advantage of the Eastern and Central Africa in the Coffee Export Sector: The Case of Burundi. African Crop Science Journal 22(Supplement s4): 987-995. doi:https://doi.org/1021-9730/2014.

Salvatore, D. (2013). International Economics. In J. Hollenbeck, J. Manias, E. Horowitz, and S. Hong (eds.): 11 th Edit. John Wiley and Sons, Inc. New York. 836pp.

Smit, A. J. (2010). The Competitive Advantage of Nations: Is Porter's Diamond Framework a new theory that explains the International Competitiveness of Countries? Southern African Business Review 14(1): 105-130.

Szenthe, A. (2019). Top Coffee Producing Countries. [https://www.worldatlas.com/articles/top-coffee-producingcountries.html] site visited on 20/4/2020.

Tanzania Coffee Board. (2012). Tanzania Coffee Industry: Development Strategy 2011/2021.

Tanzania Coffee Board. (2019). Tanzania Coffee Industry Profile. [http://coffeeboard.or.tz] site visited on $7 / 4 / 2020$. 